Peters, L.D., Pressey, A.D., and Johnston, W.J. (2016). Contagion and learning in business networks, Industrial Marketing Management, forthcoming.

\title{
Contagion and learning in business networks
}

Linda D. Peters ${ }^{1}$, Associate Professor of Marketing, Nottingham University Business School, Jubilee Campus, Nottingham, NG8 1BB, UK.

$\mathrm{T}:+44(0) 1158466602$

F: +44(0) 1158466667

Linda.Peters@nottingham.ac.uk

Andrew D. Pressey, Reader, Birmingham Business School, University House, Edgbaston Park Road, Birmingham, B15 2TY, UK

a.pressey@bham.ac.uk

Wesley J. Johnston, CBIM Roundtable Professor of Marketing, J. Mack Robertson

School of Business, Georgia State University, USA

wesleyj@gsu.edu

\section{Acknowledgements}

The authors wish to thank the anonymous reviewers, and Professor Ken Starkey and Professor Lars Mathiassen, for their comments on earlier drafts of this paper.

\section{Funding}

This work was supported by the British Academy (grant number SG101502).

\section{Contagion and Learning in Business Networks}

\begin{abstract}
The purpose of this study is to examine network learning through the application of contagion theories. The transmission of knowledge, sharing of resources, and facilitation of learning through contagion has interested both business-to-business and economic geography researchers. This study responds to calls in both research traditions for research into

${ }^{1}$ Corresponding Author
\end{abstract}


Peters, L.D., Pressey, A.D., and Johnston, W.J. (2016). Contagion and learning in business networks, Industrial Marketing Management, forthcoming.

knowledge and learning at the level of an interfirm network. More specifically, it focuses on developing an understanding of how the contagion of knowledge and ideas and the coordination of activities within a network tales place. We achieve this by drawing upon research in both network relationships dynamics and learning processes to investigate the causal mechanisms that drive contagion. We focus on two types of contagion: contagion by cohesion (i.e. the presences and closeness of direct contact with others in the network), and contagion by structural equivalence (i.e. where influence is related to the structural patterns of relationships in the network). We also identify two key mechanisms that act as a barrier to such contagion: isolation and immunity. We explore the implications of these findings for network learning opportunities, specifically learning-by-doing, learning-by-using, and learning-by-interacting.

Keywords: Contagion; Communication; Co-location; Knowledge sharing; Network learning; Cognitive consistency. 
Peters, L.D., Pressey, A.D., and Johnston, W.J. (2016). Contagion and learning in business networks, Industrial Marketing Management, forthcoming.

\section{Contagion and Learning in Business Networks}

\section{Introduction}

Between the years 541-542 AD, a pandemic (which would again later contribute to the Black Death of the $14^{\text {th }}$ century) swept across the Eastern Roman (Byzantine) Empire. It is estimated that $40 \%$ of the citizens of Constantinople were killed by the disease, which is thought to have been spread by rats and fleas hidden inside the grain distribution network. The rapid spread of disease experienced by the citizens of Constantinople owed its virulence to the highly centralized and controlled grain infrastructure that comprised of public granaries and grain ships; this ensured that the unfortunate populous were highly exposed to the virus.

Placed in a business context, the transmission of knowledge, sharing of resources, and facilitation of innovation through co-location and contagion has interested both business-tobusiness and economic geography researchers. In economic geography, the notion of learning in networks sees knowledge as a product of translation, in which the alignment of resources, such as bodies, machines, communication technologies, text (and so on), needs to be stabilized and made valid to achieve something and enable action (Muller, 2015). Innovativeness, or the openness of the firm to new ideas, relates learning and innovation processes beyond the level of the individual alone (Hurley and Hult, 1998). Both research traditions therefore have an intrinsic interest in the creation and development of networks, defined as nodes (with their associated activities and functions), connections (i.e. communication channels, resource flows, infrastructure) and the intensity of the transfer of resources (e.g. goods, people, or ideas: Lambooy, 2004). 
Peters, L.D., Pressey, A.D., and Johnston, W.J. (2016). Contagion and learning in business networks, Industrial Marketing Management, forthcoming.

Research in business-to-business networks has highlighted issues such as continuity and the presence or absence of connections (Håkansson and Ford, 2002). In the economic geography literature, Bartsch, Ebers and Maurer (2013) argue that the structure and quality of project team members' social ties with their intra-organizational colleagues (i.e. their social capital) affects their opportunities, motivation and ability to share knowledge across project boundaries. As Grabher and Ibert (2006) point out, for economic geography a relational understanding of embeddedness (associated mainly with the work of Granovetter) provided a popular metaphor around which the empirics of regional performance could be built. Contrary to much of the prevailing literature, Geldes, Felzensztein, Turkina and Durand (2015) found that geographical proximity was less relevant to cooperation in networks than either cognitive and/or social proximity. They cite the need for more research in understanding which types of activity have a greater impact on the creation of active externalities and benefits for networks. In addition, and regardless of geographical proximity, Fitjar and Rodriquez-Pose (2015) highlight the importance of local context in understanding firm behaviour and networking activity.

Therefore the metaphor of the spread of a major epidemic seems appropriate, as it allows us to highlight both the structural and configuration aspects of contagion and social network analysis (as per Burt, 1987), with concepts such as structural equivalence and the notion of the individual as embedded within a wider network of institutions (as per Granovetter, 1985), and concepts such as cohesion. By drawing upon both of these research traditions, we address a concern in the field of economic geography that a focus on the network governance approach and notions of embeddedness alone bypasses alternative (and older) traditions such as the social network approach (Grabher, 2006). It also allows us to explore not just what Grabher and Ibert (2006) call communality (robust and thick ties that 
Peters, L.D., Pressey, A.D., and Johnston, W.J. (2016). Contagion and learning in business networks, Industrial Marketing Management, forthcoming.

are firmly rooted in personal familiarity and social coherence) but also sociality (re-activating ties through ongoing face-to-face encounters) and connectivity (the task oriented subject matter of a project).

The use of metaphor (in this instance we use the metaphor of the spread of disease) has a long tradition in the study of organisations. Morgan's (1986) seminal work used several metaphors to develop an understanding of organisations related to philosophical and sociological theory (Morgan, 2011). Morgan (2011) maintains that in the use of metaphors, we generate partial truths that may nevertheless resonate and offer genuine understanding even if they are not strictly or literally true. We use "... what we know to negotiate and understand the unknown" (Morgan, 2011: 463, emphasis in the original). In particular, he suggests that new metaphors are needed for understanding the shift in organisational forms from hierarchical structures to flat networks (Oswick and Grant, 2015). We see the metaphor of contagious disease as offering potentially useful and relevant insights into learning processes in such 'flat network' structures.

Research in economic geography has highlighted the role of networks in the coordination and transmission of knowledge and the diffusion of innovation (Lambooy, 2004). Knowledge is diffused through patterns that are either based on spatial contiguity or on aspatial networks (Maggioni, Nosvelli, and Uberti, 2007), or what Muller (2015) terms topographical space (or metric distance) versus topological space (where distance and scale are functions of the relations in a network). However, "the economic geography literature [has been] mainly concerned with firm innovation" rather than individual knowledge and learning (Rutten, 2016: 15). Lambooy (2004) identifies contagion as a key approach in understanding diffusion in networks, and highlights the strengthening of already developed 
Peters, L.D., Pressey, A.D., and Johnston, W.J. (2016). Contagion and learning in business networks, Industrial Marketing Management, forthcoming.

ties and structures (i.e. embedded relations) as necessary for the formation of a successful regional innovation system. They suggest examining diffusion and the distribution of information or knowledge as a field-process in which interpersonal contacts are viewed as part of a field of general forces, where such forces could include trust and embeddedness (Lambooy, 2004).

Bartsch, Ebers and Maurer (2013) found that strong relational and cognitive ties among project teams and their colleagues outside the project can be an important source of continuity and organizational stability in the discontinuous setting of project-based organizations. Walls and Paquin (2015) call for more research on how shaping and sharing a vision takes place within a network. They recognise that intermediaries play an important role in this process, as they spur institutionalisation by helping to develop shared norms of action, reducing the cognitive barriers and the mental distance between those concerned. They go on to suggest that future research should explore the nature of relationships, rather than resources, in the network (Walls and Paquin, 2015). This paper responds to such calls for research that addresses the everyday relationships and social practices that facilitate learning, particularly in temporary sites of production and networks of actors (Rutten, 2016; Jones, 2014; Watson, 2012; Bathelt and Spigel, 2012; Jones and Murphy, 2011; Certomà, 2011; Bathelt and Glückler, 2011; Pain, 2008; Faulconbridge, 2007; Giuliani, 2007; Murphy, 2006; Yeung, 2005; Ettlinger, 2003), as part of the broader relational turn in economic geography spanning the last two decades (Jones and Murphy, 2011; Yeung, 2005; Boggs and Rantisi, 2003; Bathelt and Glückler, 2003; Amin, 2001; Amin and Thrift, 2000; Crang, 1997).

Iyengar, Van den Bulte, and Choi (2011), discussing the mechanisms of social contagion, propose that contagion research is moving from investigating whether to why 
Peters, L.D., Pressey, A.D., and Johnston, W.J. (2016). Contagion and learning in business networks, Industrial Marketing Management, forthcoming.

contagion is at work. They combined network with co-location data to examine how different mechanisms may be operating over different kinds of ties and for different kinds of actors (nodes). Thus, it was not simply the presence or absence of contagion, but the way in which contagion operated that was of interest. They therefore advise researchers to investigate the causal mechanisms driving contagion, as understanding such mechanisms is important both theoretically and managerially. This gap is also highlighted by Jones and Murphy (2011:2) who maintain that "practice-oriented research represents an important basis from which to develop economic geographical theories". This is later re-emphasises by Jones (2014:11) who suggests that "learning within firms, clusters, and industries is driven by more than simply the aggregation of individual sources of human capital; it is instead the product of collectively legitimated (everyday) social practices wherein and through which knowledge is embedded". The advantage of such an approach, Jones maintains, is that it opens up fruitful new potential for theorising the nature of agency in the space economy.

We address the gap identified by Iyengar et al. (2011) by examining not just whether, but also how the transmission of knowledge, sharing of resources, and facilitation of innovation through co-location and contagion operated between members in two business network case studies. By focusing on the social practices of the network members, we embed knowledge development and dissemination within the legitimised social practices observed, as extolled by Jones (2014). This allows us to explore how contagion might help or hinder learning processes in newer organisational forms, such as flat networks (Oswick and Grant, 2015). Our contribution is to identify and explore several mechanisms that facilitate knowledge dissemination and learning processes in networks through behavioural and attitudinal changes in network members in order to understand how shaping and sharing a vision takes place (Walls and Paquin, 2015). We do this by using metaphor in identifying and 
Peters, L.D., Pressey, A.D., and Johnston, W.J. (2016). Contagion and learning in business networks, Industrial Marketing Management, forthcoming.

exploring two types of contagion: contagion by cohesion (i.e. the presences and closeness of direct contact with others in the network) and contagion by structural equivalence (i.e. where influence is related to the structural patterns of relationships in the network). As suggested by Iyengar et al. (2011), we not only investigate the causal mechanisms driving these two types of contagion, but we also identify two key causal mechanisms that act as a barrier to such contagion: isolation and immunity. The paper is structured as follows. We begin with an overview of contagion theories, where we evaluate their usefulness in understanding learning in a network context, followed by a discussion of learning in networks. The remainder of the study empirically examines the application of contagion theories to network learning.

\section{Contagion theories}

A number of theories have attempted to explain the communication practices of networks (such as Cognitive Theories, Consistency Theories, Homophily, and Theories of Social Capital). We employ Contagion Theories as they are arguably the most developed and understood mechanism used to examine the emergence of communications networks (Monge and Contractor, 2003). Contagion theories are a family of related theories that examine how exposure or contact may lead to social influence (Social Information Processing), imitation and mimetic behaviour (Social Learning Theory and Institutional Theory), and similarity in positions and roles within the network structure (Structural Theory of Action: Monge \& Contractor, 2003).

Contagion Theories are premised on a disease metaphor, where actors are exposed to attitudes, behaviour and information (Burt, 1980). They seek to explain network members' knowledge, attitudes and behaviour based on this exposure to the attitudes, information and behaviour of others (Rogers \& Kincaid, 1981). The extent of this exposure will determine the 
Peters, L.D., Pressey, A.D., and Johnston, W.J. (2016). Contagion and learning in business networks, Industrial Marketing Management, forthcoming.

alignment between actors' beliefs and attitudes (Carley, 1991), and is defined as a convergence model of communication (Rogers and Kincaid, 1981). Convergence of attitudes and understanding is important as it gives rise to cognitive consistency, which is seen as a prime motivation for changes in beliefs, attitudes, and/or behaviours if these are not psychologically consistent (Festinger, 1957). This is important for network learning processes, as divergence creates boundaries between actors that may be difficult to breach (Carlile, 2004). Contagion theories seek to explain “...networks as conduits for 'infectious' attitudes and behaviour" (Monge and Contractor, 2003: 173). Hence, contagion theory provides a useful framework to examine how communication and knowledge is premised on emergent communication networks based on actors' cognitions and relations with other actors. While cognitive consistency may be seen as a useful step in learning in networks, the other side of the coin, groupthink, raises concerns regarding the desirability and effectiveness of those learning outcomes. Groupthink, where dissent and alternative views within a group are suppressed or ignored, can lead to dysfunctional decision-making and unintended consequences (Esser, 1998). Counterintuitively, Esser found that group cohesion was found to be less a predictor of groupthink than factors such as the insulation of group members from other sources of information and alternative points of view from outside the group. In addition, methodical decision-making procedures and informing group members that they will be held individually accountable for group decisions have been found to help groups avoid groupthink (Esser, 1998)

In particular, contagion by cohesion (i.e. direct contact with others in the network) and by structural equivalence (where influence is related to the structural patterns of relationships in the network) are two key concepts examined in contagion theoretical studies. These reflect two key approaches to understanding networks. As Grabher (2006) notes, on 
Peters, L.D., Pressey, A.D., and Johnston, W.J. (2016). Contagion and learning in business networks, Industrial Marketing Management, forthcoming.

the one hand, cohesion reflects a governance approach (typified by the work of Granovetter and his theory of strong and weak ties in relation to personal relations and networks), which concentrates on the institutional and social contexts within a network. On the other hand, structural equivalence focuses on the network position and structure or pattern (typified by the work of Burt and his theory of structural holes) of network relations.

In applying the metaphor of contagion and disease to learning processes in networks, we can see that concepts such as exposure, transmission, and diffusion are common to both the spread of disease and learning processes in networks. In addition, in both instances a material change in the state of that which is infected - either the human body by disease, or the network by a change in network-level properties such as shared practices and processes. Thus, we can develop from these commonalities between the target (network learning) and the source (disease) concepts a generic structure that we can map (Cornelissen, 2005). We map this structure by focusing on contagion by cohesion and contagion by structural equivalence and their effects on behaviour and attitudes, as well as the barriers to such contagion.

\subsection{Behaviour and attitudes through contagion}

Contagion theories have been employed to explain actors' behaviours, including absenteeism, job-seeking, and voluntary turnover. For example, Krackhardt and Porter (1986) found that employees who were regularly absent were more likely to be connected through friendship ties. In a comparative study, Feeley and Barnett (1996) studied staff turnover at a supermarket, finding that structural equivalence and social influence networks were an effective predictor of staff turnover. In a study of students' decisions to apply for 
Peters, L.D., Pressey, A.D., and Johnston, W.J. (2016). Contagion and learning in business networks, Industrial Marketing Management, forthcoming.

employment at particular organizations, Kilduff (1992) found that such practices were influenced by their friendship networks.

Many contagion theories (particularly those underpinned by social information processing theory) have focused on cohesion and the direct contact with others in the network. They contend that contagion processes over time should lead to a convergence in (or homogenization of) attitudes or actions, and to some form of network knowledge equilibrium where similarities in attitudes are achieved through interaction. Krackhardt and Brass (1994) questioned this assumption, arguing that the influence actors have over one another is contingent on both actors' exposure to information and their interaction with other actors. Two further studies have illuminated social influence in networks. In the first, Krassa (1988) argued that social influence is dependent on the number of people an actor comes into contact with, and is influential before an actor adopts an attitude or behaviour. Put another way, an actor has a threshold level of contact with other actors before they will adopt a particular attitude or behaviour (Granovetter, 1978). Further, Rice (1993) argued that network contagion theories of social influence should also take into account the level of ambiguity or novelty of a situation or task, proposing that actors are more likely to succumb to social influence when faced with an ambiguous task.

Contagion theories have also examined the structure of an actor's relationships, and how this structure influences subsequent attitudes and behaviour. In particular, structural equivalence refers to actors having similar network relations to other actors in the network by occupying similar positions in a social system through having identical ties with other network members (Grabher, 2006). They would therefore have a similar influence on workplace attitudes (Monge and Contractor, 2003) through mutual awareness and 
Peters, L.D., Pressey, A.D., and Johnston, W.J. (2016). Contagion and learning in business networks, Industrial Marketing Management, forthcoming.

observation, which would stimulate regional innovation and learning (Grabher, 2006). Burt (1987) maintained that contagion of the adoption of new drugs between medical practitioners was less a result of cohesion and socialisation than of their occupation of similar positions in the social structure (i.e. their structural equivalence). More recently, Burt (2004) maintains the importance of network position by stating that by bridging a structural hole (defined as a gap in the connectedness between network members) an actor is able to have access to a wider information screen. He maintains that those who are close to structural holes may be more likely to have good ideas, as they will enjoy greater access to alternative ways of thinking (Burt, 2004).

Studies across various organisational contexts demonstrate that actors in the same social circles were more likely to perceive agreement with others (Friedkin, 1984), employees who were structurally equivalent reported similar attitudes concerning product development (Walker, 1985), and employees who regularly communicated with one another shared comparable interpretations of corporate events (Rentsch, 1990). While structural equivalence would maintain that individuals share exactly the same network links and relationships, actors with regular equivalence have broadly similar (although not identical) network relationships (White and Reitz, 1989). Pattison (1994) contends that actors who can be characterised as regularly equivalent were more likely to share social cognitions. Thus, broadly similar patterns of network relations need not be identical to be equivalent.

\subsection{Barriers to contagion}

Contagion theories are not without their critics. One criticism is that they represent the so-called 'hypodermic needle model' of network communication practices. That is, the notion that exposure to information 'injects' values and attitudes into actors who will unquestionably 
Peters, L.D., Pressey, A.D., and Johnston, W.J. (2016). Contagion and learning in business networks, Industrial Marketing Management, forthcoming.

adopt an idea or behaviour (Monge and Contractor, 2003). Actors may also be isolated from 'message infection' through network isolation; that is the isolation of actors from the highly infectious parts of a network leading to the obstruction of powerful message content. Thirdly, applications of contagion theories have not always taken into account the possibility that an individual may display resistance or inertia towards contagious influences (Monge and Contractor, 2003). For example, the extent to which an actor adopts a particular attitude or behaviour is contingent on the actor's knowledge and confidence in assessing a situation.

Against this background, McGuire (1966) offered an explanation as to how actors may be resistant to contagion. Just as individuals may be inoculated against susceptibility to contracting disease through the exposure of trace amounts of an infecting agent, McGuire (1966) contends that actors may become immune to contagious messages if they are exposed to a weaker form of an argument and/or a counterargument. Hence, actors may gain immunity and resistance to certain accepted attitudes or behaviours through 'inoculation' with weaker contagious network messages.

The consequences of this observation suggest that some parts of networks may be immune to the reception of infecting messages, even if those 'immune' actors are linked to other actors in the network (Monge and Contractor, 2003). This is also reflected in the view that learning is a process that "...grows by increasing specialization” (Bångens and Araujo, 2002: 573), but that such specialization may hinder the acquisition of contrary forms of knowledge (Loasby, 1998). Thus, critics of contagion theories have called for greater articulation of the mechanisms that trigger contagion, the practices by which organisations influence other's actions and behaviours, and the content of messages (which may inoculate contagion between actors). 
Peters, L.D., Pressey, A.D., and Johnston, W.J. (2016). Contagion and learning in business networks, Industrial Marketing Management, forthcoming.

\section{Network learning}

While research has focused on the knowledge held by firms and their knowledge dissemination practices, less attention has been directed towards knowledge and learning at the level of an interfirm network (Lettl, Herstatt, and Gemuenden, 2006: Kauppila, Rajala and Jyrämä, 2011). Interest in organisational learning at the level of such networks, however, has been steadily increasing (Easterby-Smith, Crossan and Nicolini, 2000). Driving this is the recognition that "...organizations are collections of overlapping knowledge systems each of which may be embedded within a wider occupational community" (Araujo, 1998: 331). As we have already noted, in economic geography the notion of learning in networks sees knowledge as a product of translation (Muller, 2015). This can also be said to be true for inter-organisational networks, whose fluidity is often a key aspect of their successful translation, and consequently knowledge (Muller, 2015).

This moves research in economic geography forward by dissolving “... the crisp tieand-node cartographies into more polymorphous and overlapping network domains" (Grabher, 2006: 166). Thus, in contrast to theories of learning that focus on the information processing capabilities of learners (cf. Walsh, 1988), network learning focuses on the shared meaning constructed in situ in network contexts (Johnston, Peters and Gassenheimer, 2006), and the communication practices that support this. This reflects the view in economic geography of regional level dynamics in networks as localized pools of specialists, and the notion of regions as repositories of knowledge (Grabher, 2006).

We draw upon the definition of network learning posited by Knight and Pye (2005) in which they state that it is learning by a group of organisations as a group. It is where a change in - or the 
Peters, L.D., Pressey, A.D., and Johnston, W.J. (2016). Contagion and learning in business networks, Industrial Marketing Management, forthcoming.

development of - network-level properties such a shared practices and processes would indicate learning. This corresponds to the definition of organisational learning put forward by Popova-Nowak and Cseh (2015: 316) as “... a social process of individuals participating in collective situated practices and discourses that reproduce and simultaneously expand organisational knowledge." Bartsch, Ebers and Maurer (2013) maintain that it is the application and use of newly acquired knowledge that is the primary indicator that organizational learning has taken place.

Thus, focusing on the practices that characterize how learning processes are created, maintained and changed allows us to know if organizational learning has taken place. Bångens and Araujo (2002) highlight three types of collective situated learning practices: learning-by-doing (routines and repetitious tasks); learning-by-using (dissimilar capabilities that are embodied in goods and services which actors have access to); and learning-byinteracting (joint problem solving between actors). Learning-by-doing over time may lead to a convergence in attitudes or actions, learning-by-using may enhance social influence effects (particularly if the level of ambiguity or novelty of a situation or task is high), and learningby-interacting may lead to network knowledge equilibrium where similarities in attitudes are achieved through interaction. Thus, understanding learning in networks requires an examination of the learning processes between network members that may then be applied to firm level outcomes. These learning processes recognise the complex inter-relationship between humans and non-human elements in the network, or what Muller (2015) terms the hybridity of actor-networks.

All three of these practices rely on communication. As communication has been identified as an important contributor to team learning and project success (Robey, Khoo and Powers, 2000; Sole and Edmondson, 2002), then understanding how the contagion of 
Peters, L.D., Pressey, A.D., and Johnston, W.J. (2016). Contagion and learning in business networks, Industrial Marketing Management, forthcoming.

knowledge and ideas and the co-ordination of activities through effective communication within a network tales place is an important contribution, and one that should be encouraged. We thus propose that there is clearly a need for a better understanding of the communication activities and learning practices that facilitate the learning opportunities that firms find so valuable. We argue that communication and network learning capabilities can be examined through the application of contagion theories, as such theories seek to understand how actors are exposed to attitudes, behaviour and information and how this diffuses through networks.

\section{Methodology}

\subsection{Case study selection and context}

We have chosen to focus our exploration of network learning through the application of contagion theories by examining the communication practices in two project teams in the construction industry. Learning processes in construction network relationships are interesting because they can change radically from project to project and thus the ability of members to form cognitive structures that support learning is problematic (Dubois and Gadde, 2002). Such changes limit the learning processes of trial, feedback and evaluation. However, they may also support the development of new ideas and innovation because of the variation in network activities and membership (Weick and Roberts, 1993; Brusoni, 2005; Chiu, 2009), although this innovation may not be shared or disseminated beyond the project network.

Sampling of the two construction projects examined was theoretical (Yin, 1994), and based on the opportunities they provided to observe network learning processes. In one case ContinuousProject - the build took place over several sequential phases. However, the same team members remained engaged throughout the life of the project and thus an unbroken 
Peters, L.D., Pressey, A.D., and Johnston, W.J. (2016). Contagion and learning in business networks, Industrial Marketing Management, forthcoming.

knowledge base was established for the project. In the other case - FragmentedProject - the build took place in two discrete phases with different team members in each of the two phases. By collecting data from two different cases, the researchers were able to compare and contrast the data collected from each case.

The first case study (ContinuousProject: costing approximately $£ 8.5$ million) was a project creating office space and conference and training facilities. The second case study (FragmentedProject: approximately $£ 8$ million) related to the construction of a combined heat and power plant (CHP) for a large-scale institutional user. In Table 1 we summarise the key features of each case. The management teams (consisting of the client representatives, architect, design team, and contractor representatives) were of approximately equal size on each project, and details are provided in Tables 1 and 2. 
Peters, L.D., Pressey, A.D., and Johnston, W.J. (2016). Contagion and learning in business networks, Industrial Marketing Management, forthcoming.

Table 1

Case Summaries

\begin{tabular}{|l|l|l|}
\hline & Case 1: ContinuousProject & Case 2: FragmentedProject \\
\hline Value & $£ 8.5$ million & $£ 8$ million \\
\hline Purpose & $\begin{array}{l}\text { Office accommodation and } \\
\text { conference/training facilities }\end{array}$ & Combined heat and power generation \\
\hline Supplier & $\begin{array}{l}\text { A leading construction, development and } \\
\text { services group in the UK. The Group } \\
\text { employs 11,400 people worldwide and has } \\
\text { annual revenue of £2.1bn. }\end{array}$ & $\begin{array}{l}\text { A leading construction and regeneration } \\
\text { group in the UK. The Group employs over } \\
8,500 \text { people and has annual revenue of over } \\
£ 2.5 \text { bn. }\end{array}$ \\
\hline Customer & Training and Education Provider & $\begin{array}{l}\text { Large-scale site with district heating system to } \\
\text { approximately 30 buildings. }\end{array}$ \\
\hline Level of Risk & $\begin{array}{l}\text { Medium, new variant of energy efficient } \\
\text { construction technology previously used by } \\
\text { this client in other buildings. }\end{array}$ & $\begin{array}{l}\text { High, if successful this will be the first } \\
\text { working CHP plant utilising this form of } \\
\text { energy production technology in the UK. }\end{array}$ \\
\hline $\begin{array}{l}\text { Planning time } \\
\text { frame }\end{array}$ & $\begin{array}{l}9 \text { months in planning, this data was collected } \\
\text { over the 24 month construction period. }\end{array}$ & $\begin{array}{l}\text { 3 years in planning, this data was collected } \\
\text { over the 24 month construction period. }\end{array}$ \\
\hline
\end{tabular}

Table 2

Respondent Demographics

\begin{tabular}{|c|c|c|c|c|c|}
\hline & $\begin{array}{l}\text { Client Team } \\
\text { (e.g. Project } \\
\text { Director, } \\
\text { Project } \\
\text { administrator }\end{array}$ & $\begin{array}{l}\text { Client Team } \\
\text { Representatives } \\
\text { (e.g. Project } \\
\text { Managers and } \\
\text { their Quantity } \\
\text { Surveyor) }\end{array}$ & $\begin{array}{l}\text { Design Team } \\
\text { (e.g. Architect, } \\
\text { Mechanical } \\
\text { and Electrical } \\
\text { Engineers, } \\
\text { Structural } \\
\text { Engineers) }\end{array}$ & $\begin{array}{l}\text { Other } \\
\text { Specialists } \\
\text { (e.g. Clerk of } \\
\text { Works, } \\
\text { Landscape } \\
\text { Specialists, } \\
\text { Acoustic } \\
\text { Specialists) }\end{array}$ & $\begin{array}{l}\text { Contractor } \\
\text { Team } \\
\text { (e.g. Project } \\
\text { Managers, } \\
\text { and their } \\
\text { Quantity } \\
\text { Surveyor) }\end{array}$ \\
\hline ContinuousProject* & 3 & 3 & 4 & 5 & 3 \\
\hline FragmentedProject & 3 & 1 & 5 & 5 & 4 \\
\hline
\end{tabular}

* As both projects were in the same geographic region of the UK, some team members were present on both projects.

While the role of other members in the wider network (e.g. sub-contractors and other supply chain partners, and external stakeholders such as planning authorities and local council officials) are no doubt important, we chose to focus our data collection and observations on the client, middle managerial and administrative functions, design team, and other specialist network members. This provided a useful boundary in terms of learning processes as these are the network members who meet on a regular and frequent basis, both formally and informally, and who deal directly with the practical issues and problems that arise in relation to the project design and construction. Due to an anonymity agreement between researchers and informants, we can provide only general information for the nature of each project. 
Peters, L.D., Pressey, A.D., and Johnston, W.J. (2016). Contagion and learning in business networks, Industrial Marketing Management, forthcoming.

\subsection{Data collection and analysis}

The data collected for this study consists primarily of 45 in-depth semi-structured interviews and two focus groups conducted with managers of two UK construction projects over a period of twenty-four months. In addition, 14 design team progress meetings were attended (eight for ContinuousProject and six for FragmentedProject). In each meeting, official progress documents were collected and field notes were made. The interviews lasted on average 90 minutes and the focus groups lasted two hours or more; all were digitally recorded. The data were transcribed and then coded using AtlasTI v6 software; following the coding procedure outlined by Strauss and Corbin (1998). In order to aid internal validity, multiple perspectives were collected through interviewing actors at different points in the network (Yin 1994). To facilitate external validity we frequently drew on the expertise of a senior executive in the construction industry (who was not a member of either project team and was thus impartial) to help understand the issues arising from the data and our interpretations of them. This industry expert held a management board level position in a major UK construction company and had over thirty years' experience in the industry.

In addition, to ascertain communication behaviours we drew upon the work of Mohr and Nevin (1990) who characterise frequency, direction (uni or bi-directional) and modality (more formal vs. more informal modes) as important aspects of communication. We therefore asked each respondent to complete a questionnaire in which they stated who they communicated with (i.e. their 'ego network'; Monge and Contractor, 2003), on a three-point scale $(3=$ frequent/sustained, $2=$ moderate/some, or $1=$ infrequent/occasionally), and how often they communicated with them. This was collected for both formal (meetings, memos, official documents and sign-offs) and informal communication modes. 
Peters, L.D., Pressey, A.D., and Johnston, W.J. (2016). Contagion and learning in business networks, Industrial Marketing Management, forthcoming.

The communication behaviour data was then analysed using UCINET 6 software. A pictorial representation of the network connections (i.e. a sociogram) for both formal and informal communication modes for both projects is given in Appendix 1. Firstly, postulating that the influence of one node upon another declines with the distance between them, the geodesic distance matrix (the distance between two nodes as the number of links in the shortest path between them) can be used as an index of influence or cohesion in the network (Hanneman and Riddle, 2005). As we have used value data (the frequency of communication) to calculate this, the distance between two actors is defined as the strength of the weakest path between them. In addition, to examine how actors may be resistant to communications if they are exposed to a weaker form of an argument and/or a counterargument, we examine the hierarchical nature of the network. This is because in hierarchies, contagious messages may become weaker as they are passed down the hierarchy. We have used Krackhardt's graph theoretical dimensions of hierarchy (Krackhardt's GTD), as this measure tells us something about the hierarchical structure of the network (Hanneman and Riddle, 2005). In a pure hierarchical form, every node would have a directed connection and have an in-degree of 1 (one inward directed contact) except the boss (i.e. A to B to C to D). We summarise this analysis in Table 3, which looks at the network level data for each project according to either formal or informal communication mode. 
Peters, L.D., Pressey, A.D., and Johnston, W.J. (2016). Contagion and learning in business networks, Industrial Marketing Management, forthcoming.

Table 3: Network Cohesion and Structural Equivalence by Communication Mode

\begin{tabular}{|c|c|c|c|c|c|}
\hline & $\begin{array}{c}\text { Data } \\
\text { type }\end{array}$ & $\begin{array}{c}\text { ContinuousProject } \\
\text { Formal } \\
\text { Communications }\end{array}$ & $\begin{array}{c}\text { ContinuousProject } \\
\text { Informal } \\
\text { Communications }\end{array}$ & $\begin{array}{c}\text { FragmentedProject } \\
\text { Formal } \\
\text { Communications }\end{array}$ & $\begin{array}{c}\text { FragmentedProject } \\
\text { Informal } \\
\text { Communications }\end{array}$ \\
\hline $\begin{array}{c}\text { Geodesic Distance } \\
\text { (Average distance) }\end{array}$ & Value & 1.46 & 1.45 & 1.26 & 1.33 \\
\hline $\begin{array}{c}\text { Distance-based cohesion } \\
\text { (Compactness, range 0 to 1; larger } \\
\text { values indicate greate } \\
\text { cohesiveness) }\end{array}$ & Value & 0.77 & 0.78 & 0.87 & 0.84 \\
\hline $\begin{array}{r}\text { Distance-weighted fragmentation } \\
\text { (Breadth) }\end{array}$ & Value & 0.23 & 0.23 & 0.13 & 0.17 \\
\hline $\begin{array}{r}\text { Krackhardt GTD } \\
\text { (connectedness) }\end{array}$ & Directed & 1.00 & & & \\
\hline (hierarchy) & Directed & .63 & .87 & .64 & .87 \\
\hline (efficiency) & Directed & .81 & .79 & .68 & .74 \\
\hline (Least upper bound) & Directed & 1.00 & 1.0 & 1.0 & .91 \\
\hline
\end{tabular}

In our use of the contagion metaphor, we draw upon the work of Cornelissen (2005) and the domains-interaction model in which a correspondence between terms and concepts is constructed rather than deciphered (as would be the case in the more commonly found comparison model of metaphor use), and where the resulting image and meaning is creative. While the comparison model relies on finding a feature already present in the target and then relating that to features shared by both the target and source concept, the domains-interaction model allows for inferences beyond these similarities, and is thus creative with the features of importance which emerge. It allows for the generation and creation of new meaning beyond a previously existing similarity (Cornelissen, 2005). This new meaning is understood as flowing from an interaction of 'seeing as' or 'conceiving as', where understanding a metaphor creates similarity instead of simply emphasizing and reporting pre-existing similarities in the source and target concepts. The first phase of the domains-interaction model requires us to develop a generic structure, which we outlined at the beginning of section three, with shared concepts such as exposure, transmission, diffusion, and change. The second phase is the development and elaboration of the blend, in which elements from both the target and the source concepts are elaborated. This was discussed in sections 3.1 and 3.2 in relation to behaviour and attitudes through contagion and the barriers to contagion. The 
Peters, L.D., Pressey, A.D., and Johnston, W.J. (2016). Contagion and learning in business networks, Industrial Marketing Management, forthcoming.

final phase is that of emergent meaning, where the meaning that has been elaborated is linked or translated back to the target concept. This we now do in presenting our findings.

\section{Findings}

We introduce here our within-case findings and analysis. We begin our discussion of each case by providing a general context and reporting the results of our communication behaviour data in relation to cohesion and structural equivalence. We then examine the mechanisms that help explain how behaviour and attitudes may be influenced, and how barriers may hinder, learning in the network.

\subsection{Case study one: ContinuousProject.}

ContinuousProject's remit was to create office space, conference, and training facilities. As the final months leading up to the commencement of the build followed, the client mooted the possibility of a second phase in order to add additional office space. In one meeting jokes were made about negotiating with the current contractor to continue with phase two: 'if they delivered phase 1 ok'. In fact, all those involved in the first phase of the build continued to be employed for the second phase of the project, which they all considered as a bonus and in no small part due to the positive team-working atmosphere and willingness of everyone to accommodate the client in this two phased development and approval process.

Turning to the network data collected, we see a number of interesting features relating to the level of cohesion on the project. For ContinuousProject the strength of the geodesic distance for both formal and informal communication modes shows that on average these were fairly infrequent (1.46 and 1.45), but with compact (.77 and .78) and less fragmented (.23 and .23) communication patterns between network members. Therefore, we see a pattern 
Peters, L.D., Pressey, A.D., and Johnston, W.J. (2016). Contagion and learning in business networks, Industrial Marketing Management, forthcoming.

of relatively dense communication patterns where ties exist, but a more fractured picture in relation to the establishment of ties. Where ties are strong, timely access to information and a greater motivation to share information is expected. However, those who are weakly tied are likely to travel in different circles from one another, thereby opening up access to new information (Granovetter, 1978). In terms of contagion, this governance profile of strong ties between some members and weak ties between others may have offered a useful trade-off between information and knowledge acquisition and its dissemination.

In relation to structural equivalence, the Krackhardt's GTD results in table 3 tell us that in terms of connectedness in the ContinuousProject network all the actors ( 1 for formal communications) and almost all (.87 for informal communications) are embedded in a single structure, which is a common condition of hierarchical structures. Thus, all actors were engaged in formal communication channels within the network's hierarchical levels and were therefore easily reachable in terms of communication flows. For informal communication channels there were relatively few individuals (only 13\%) who were not reachable through informal communication channels. Only a moderate proportion of all tied pairs have reciprocal ties, and are thus non-hierarchical (.63 and .54). In terms of efficiency (where each actor having communication from a single boss would be the most efficient form), we see that the network is relatively efficient (.81 and .79). These are small differences in the deviation from a perfectly hierarchical form (with an in-degree of one for each node, calculated as the difference between the actual number of links minus 1 and the maximum possible links). Finally, the least upper bound (where each actor pair, except those that include the boss, has an actor that directs ties to both actors in the pair - i.e. command is unified) shows that all actors have a common boss (1.00). These four measures of hierarchy show ContinuousProject communication patterns to be fairly strongly hierarchical in 
Peters, L.D., Pressey, A.D., and Johnston, W.J. (2016). Contagion and learning in business networks, Industrial Marketing Management, forthcoming.

structure. There appears to be little evidence here of structural holes (Burt, 2004), as most of the network members occupy similar positions in the social system (Grabher, 2006) through having identical ties (for formal communication) and almost identical ties (for informal communication) and thus would have similar influences on the attitudes in the network (Monge and Contractor, 2003). We now go on to discuss how these results, together with the interview data, help us to understand the mechanisms that facilitate and inhibit contagion.

\subsubsection{Behaviour and attitudes through contagion on ContinuousProject}

One mechanism that influenced the contagion of attitudes was through friendly social influence. An example of this was in the team dynamics in the meetings held. In the initial meetings between the contractor and the client teams, both groups tended to sit opposite one another in the room. One of the engineers often joked about this, and in one meeting actually got up, moved across the room, and sat with the contractor. As the project progressed the group dynamic changed and seating in meetings was much more informal and random, while actors seemed more integrated and socialised as construction progressed. As one team member commented: "I think the team generally has been a very good team, they all, you know, we all have a laugh and a joke and we've got a job to do but it's a good job to do". With a pattern of relatively dense communication where ties existed (i.e. within ties), but a weaker pattern of ties being established (i.e. between ties) in the communication behaviour data, such social influence becomes a useful tool in encouraging contagion between members who are not directly tied. This supports the view that workplace humour has been seen to help defuse stressful situations and to facilitate social structure and group cohesion (Coser, 1959).

\subsubsection{Barriers to contagion on ContinuousProject}


Peters, L.D., Pressey, A.D., and Johnston, W.J. (2016). Contagion and learning in business networks, Industrial Marketing Management, forthcoming.

Several barriers to contagion were evident in ContinuousProject. At an early phase in the project there were lengthy discussions concerning version control of documents. One engineer expressed his desire to employ an IT system, but this was not ready at the beginning of the project. The contractor had their own system that they were keen to use, but the client was resistant as they recognised that they would have had to learn how to use it, so the traditional methods of email and exchange of documents prevailed. Such difficulties are well recognised in the research on knowledge sharing and exchange using I.T. (Cabrera and Cabrera, 2002), and represent a barrier to translation (Muller, 2015). Although this practice worked reasonably well, all actors agreed that an integrated I.T. system would have worked better; the issue was one of ownership of the system (i.e. the client, the architect, or the contractor), which could not be resolved.

Again, at an early phase in the project, several actors were concerned how issues would be dealt with if they were no longer present to help resolve them. An example of this was the structural engineer who was anxious whenever problems were raised (this included issues related to the car parking level and materials being proposed for use in the building). His own concerns on using non face-to-face (i.e. I.T. based) communications surfaced in an interview: 'But it's getting more impersonal. And I think sometimes that it's great for speed, but not good for relations because you then actually feel that somebody's going to get stitched up'. Trust, for him, was something of an issue when using such communication media. Another respondent commented that while co-location of team members geographically was not a particular issue, they did recognise that "...in terms of teams, or the maintenance of teams, over a number of projects, it's beneficial." In part, co-location and greater face-to-face contact enabled closer ties with other supply chain firms through what Grabher and Ibert (2006) termed sociality, however not at the expense of expertise (what they 
Peters, L.D., Pressey, A.D., and Johnston, W.J. (2016). Contagion and learning in business networks, Industrial Marketing Management, forthcoming.

termed connectivity): “I would rather use a local person because ... we've got lots of links with our local supply chain, but if there's a specialist that we need then they come from wherever they come from." We see here some consideration of the trade-offs between spatial diffusion and knowledge spill-overs that can occur when co-location is a feature of the network (i.e. where space matters most) and a-spatial relational networks that are formed irrespective of geography (Maggioni et. al. 2007).

These results point to a network where groups of actors are clustered. The communication behaviour is compact and less dispersed, but not widely connected across the whole network, and communication patterns are hierarchal. Reflecting the importance of communication flows of this hierarchy, one project manager commented: 'We don't tend to look at the [technical] drawings that much. Or really have a need to understand them really. We are - in the drawing sense, we are just a distribution hub basically'. This highlights one reason for such clustering; the fragmentation of expertise on such construction projects. Isolation between actors may not simply be physical, but may also be due to the wide variance in professional backgrounds and specialist knowledge, and this might have hampered understanding (Corsaro, Cantù and Tunisini, 2012). To address this, and to facilitate the sharing of more tacit knowledge, a wide variety of simple artefacts such as the use of drawings, progress charts, reports, and photographs (as well as a sense of humour in actors' interactions with one another) acted as boundary spanning objects between actors and provided ways of sharing new knowledge in the project community. Such artefacts are valuable particularly when a task or project involves "...many actors attempting to coordinate activities in a fixed time period where the goal may be relatively clear but the ways in which it can be achieved are not" (Mason and Easton, 2009: 7). Previous studies have demonstrated that simple artefacts act as a means to negotiate interpretations, practices and priorities, and 
Peters, L.D., Pressey, A.D., and Johnston, W.J. (2016). Contagion and learning in business networks, Industrial Marketing Management, forthcoming.

as a way of capturing knowledge across diverse communities of practice (Cacciatori, 2008; Brown and Duguid, 1991). For example, at every meeting actors would examine the progress report, which consisted of a large complex Gantt chart outlining all workflows and time scales, and discuss what factors impinged on the progress of the project. Despite its complexity, this provided meaning for all actors despite their specialisms. In addition, each month the contractor would include pictures of the building in his report, which afforded the client a visual representation of progress. By fostering cognitive ties amongst network member, such artefacts may provide an important source of continuity and stability in such discontinuous settings (Bartsch, Ebers and Maurer, 2013).

Although hierarchical in structure, the nature of progression on the project (where team members remained on the project throughout all of the build phases) and the variety of connections between network members meant that immunity was lessened. ContinuousProject members were less resistant to messages, as they may have come from several sources in the network (i.e. not just 'top-down'). This openness to 'message infection' could be seen by the extensive use of humour as a means of achieving social influence between network members. Humour at work helps defuse stressful situations as well as to communicate expectations (Hatch, 1997; Roy, 1959), and to help create social structure (Coser, 1959). Humour may thus be seen as a way to reduce the undesirable content of messages and thus facilitate contagion between actors.

\subsection{Case study two: FragmentedProject.}

FragmentedProject consisted of a combined heat and power (CHP) plant for a largescale institutional user that would eventually allow the client to provide up to $90 \%$ of its own electricity needs. Unlike the ContinuousProject build, the FragmentedProject construction 
Peters, L.D., Pressey, A.D., and Johnston, W.J. (2016). Contagion and learning in business networks, Industrial Marketing Management, forthcoming.

operated as two very distinct phases (the build and fit-out stages). In the first phase, the building (often referred to by the design team as 'the shell' or 'the shed') was constructed. In the second phase, the power generation equipment was installed (referred to as the fit-out). Unlike ContinuousProject, these were largely distinct teams for each phase of the project.

Turning to the network data collected for FragmentedProject in Table 3, we see that the level of cohesion, as evidenced by the average geodesic distance, was low (1.26 and 1.33), meaning that the average distance for both formal and informal communication modes were infrequent. There was stronger compactness (.87 and .84$)$ and less dispersion (.13 and .17) of communication between these network members than those on ContinuousProject. Therefore, we again see a configuration of relatively dense communication patterns where ties exist, but a more fractured picture of ties being established. In governance terms, this would indicate that while weak ties may offer new information for the network, timely access and the motivation to share such information was lower for FragmentedProject than for ContinuousProject.

In relation to structural equivalence, the Krackhardt's GTD results in Table 3 shows their connectedness (and thus embeddedness) in a single hierarchical structure. In the FragmentedProject network, fewer actors (.64) were connected for formal communications, but more (.87) were connected for informal communications. Thus, fewer actors were engaged in formal communication channels within the network's hierarchical levels and were therefore less reachable in terms of communication flows. In other words, $36 \%$ of the actors in the network cannot be reached directly by formal communication channels, as compared to $13 \%$ for informal communication channels. The two-stage nature of FragmentedProject clearly provided a disconnect in formal communication and co-ordination activities, and made this project far more reliant on informal communication activity than 
Peters, L.D., Pressey, A.D., and Johnston, W.J. (2016). Contagion and learning in business networks, Industrial Marketing Management, forthcoming.

ContinuousProject. This indicates more in the way of structural holes. However, while Burt (2004) would maintain that the bridging of such holes may offer access to alternative ways of thinking and encourage new and better ideas, the disconnect on FragmentedProject between network members (with fewer strong ties) may have made the utilisation of such ideas problematic.

Only a moderate proportion of all tied pairs have reciprocal ties, and are thus nonhierarchical (.68 and .74). In terms of efficiency, the FragmentedProject network is quite efficient (.85 and .91). Finally, the least upper bound shows that all actors have a common boss (1.00). These four measures show communication patterns to be very strongly hierarchical in structure, particularly for formal communication flows in the hierarchy. While such hierarchy in the FragmentedProject network was more pronounced, and while this may have led to greater efficiency in network communications (in particular the transfer of the design team to the contractor in phase one), it may also have led to less effectiveness in that it reinforced the more fragmented nature of the two-phase project and thus inhibited the convergence of attitudes and understanding and the resulting cognitive consistency (Rogers and Kincaid, 1981).

\subsubsection{Behaviour and attitudes through contagion on FragmentedProject}

The instigation of the project was based on friendship networks and trust between individuals. The phase-two client project administrator and his risk and sustainability manager were unsure of adopting the new energy producing technology and felt it would be a high-risk project. It was through their mutual respect of the Fit-out contractor who was a leading innovator in CHP energy generation that they initiated discussions of the project. Therefore, they were open-minded about the adoption and investigated it further, and 
Peters, L.D., Pressey, A.D., and Johnston, W.J. (2016). Contagion and learning in business networks, Industrial Marketing Management, forthcoming.

commissioned a feasibility report. This triggered their recognition that the project was feasible, and that they could learn from pursuing what was a radically innovative technology. In the sociograms in Figure 2, the fit-out team members sit at the periphery, connected mainly through the project administrator and the risk and sustainability manager, to the rest of the project team.

Continuity in attitudes and knowledge was facilitated in part through the transfer of the original design team to the contractor in phase one, which helped with the consistency of the design, and supported the notion that developing strong relational and cognitive ties among project teams and their colleagues outside the project can improve continuity and stability (Bartsch, Ebers and Maurer, 2013). The project administrator stated: “...had this not been the case the new team would have taken time and made potential changes out of ignorance." The client also involved the contractor ahead of the final cost of the contract being agreed. This allowed the contractor to "...help influence the design while still within the employer's fluid design process ahead of the design freeze, it allowed the contractor to prepare suppliers and contractors earlier than would normally be the case, and it helped build a sense of team work with the whole project participants rather than a potential 'contractual' approach often employed in the industry."

As with ContinuousProject, one of the key socialising mechanisms in meetings for the build team involved with the first phase of the project on FragmentedProject was the use of humour. In every meeting, there were lots of jokes both about key participants on the project and about the process of the build itself. This was often used to defuse tension, form social bonds, and to communicate tacit understanding of the issues. In the second project meeting a joke was made about one of the client's team, whose view of most project delivery 
Peters, L.D., Pressey, A.D., and Johnston, W.J. (2016). Contagion and learning in business networks, Industrial Marketing Management, forthcoming.

outcomes one actor viewed as “...'just-too-late’ delivery” (as a play on just-in-time delivery). A further socialising mechanism employed was a phase-one design team trip to visit another CHP project. The purpose of this was to observe a similar project being undertaken. This reinforced the team dynamic and afforded group cognitive consistency by enabling the team to make a pilgrimage to a special learning site (as a region or repository of knowledge; Grabher, 2006). Identifying and recognising the problems that this other project was having, they discussed how they would avoid repeating these mistakes on their project.

The second phase of the project - the fit-out stage - did not exhibit these mechanisms of social cohesion and humour, exhibiting a limited amount of what Grabher and Ibert (2006) termed communality. Meetings were more formal in demeanour, yet less structured in terms of aims and objectives, and demonstrated a lack of what Grabher and Ibert (2006) termed connectivity as well. There were rarely agendas to follow or minutes from previous meetings to refer to in order to aid the contagion of ideas. It seemed that the trust and friendship of two of the key network members cast a shadow over the ability of the fit-out team as a whole to be cohesive. This was reflected in the attitude of the project manager: "I don't need lots and lots and lots of large participation meetings, the telephone and email would nearly eliminate all the meetings." While his strong relationship with the Fit-out contractor mitigated the effect of geographical distance, for others on the team this distance proved a barrier both in terms of physical meetings, and in terms of relationship building. This supports Frigant and Lung (2002), who maintain that proximity enables the creation of a shared language between different groups, and facilitates the implementation of routines of co-ordination. Such routines were notably absent.

\subsubsection{Barriers to contagion on FragmentedProject}


Peters, L.D., Pressey, A.D., and Johnston, W.J. (2016). Contagion and learning in business networks, Industrial Marketing Management, forthcoming.

Arguably the greatest barrier to network learning for FragmentedProject was the variation in views due to the two-stages involved (build and fit-out), and the innovative technology being employed. This was recognised by the project manager who observed: "I take a position that the building team - I don't think have totally absorbed - that this project is very much about a lump of engineering that needs a roof on it whereas they are used to providing buildings in their own right that are the total focus of the project. From my perspective the building is a minor focus of the project and so there is a disparity" and that “...sometimes this leads to conflict."

This points to even greater disparities and disconnects between members in this network, related to the two-stage nature of the project and the difficulties of co-ordinating the building of the structure and the subsequent fit-out with the CHP technology. One representative for the client, who worked on both stages of the project, observed: "There is a barrier there, I think because the other [build] team work totally different to the way I do [with the fit-out team]. They are much more formally structured by meetings and notes of meetings and that approach, I believe, which seems to limit communication ... I act as a conduit." In this instance, the client representative felt that adopting an overly formalised approach to the project would inhibit flexibility. However, acting as a conduit may have increased the efficiency of the project, but also intensified its hierarchical communication structure and the isolation of network communications. As highlighted by Monge and Contractor 92003), such isolation from the highly infections parts of a networks may lead to obstruction or powerful message content. This isolation was exacerbated by the paucity of evidence of managing the process of the fit-out phase of the project. Those involved in the fit-out stage often had to recall from memory what had been agreed and specified. Thus, widely differing points of view, stronger hierarchical formal communication patterns, greater 
Peters, L.D., Pressey, A.D., and Johnston, W.J. (2016). Contagion and learning in business networks, Industrial Marketing Management, forthcoming.

reliance on informal (rather than formal) communication modes, and a fracture between the two phases of the project, led to greater message isolation.

In relation to immunity to network messages, there may have been a beneficial side to this, particularly for the project manager. He had to study specific regulations and was attempting to understand every detail and nuance of the project: "As project leader my goal is to complete the project successfully ... there is a whole range of regulatory issues and I have to be sure that I comply with what is necessary. In order to be a correctly managed and operated function you have to know all of this and take it on board, the project cannot succeed if that is wrong." Here we see what McGuire (1966) would recognise as the use of inoculation (through the focus on industry wide and generalised regulatory prescriptions) which helped him to develop immunity to the more specific network member's understandings. It allowed him to develop his own personal understanding and interpretation of the regulations, which he could then apply to the project. However, for the network members overall the fact that the structural patterns of communication in the network were strongly hierarchical, particularly for formal communication modes, meant that his immunity to message content could have been a more serious issue on FragmentedProject. One danger resulting from such isolation of group members from information and alternative points of view, and the lack of methodological decision-making in the second phase of the project, would be the increased susceptibility to groupthink (Esser, 1998). We summarise this in Table 4.

Table 4

Summary of Mechanisms of Contagion

\begin{tabular}{|l|l|l|}
\hline & ContinuousProject & FragmentedProject \\
\hline $\begin{array}{l}\text { Contagion by cohesion } \\
\text { (i.e. the presences and } \\
\text { closeness of direct contact }\end{array}$ & $\begin{array}{l}\text { A pattern of relatively dense } \\
\text { communication where ties existed, but } \\
\text { a weaker pattern of ties being }\end{array}$ & $\begin{array}{l}\text { FragmentedProject member connections } \\
\text { were more compact, yet less cohesive } \\
\text { overall. Thus, where ties existed they }\end{array}$ \\
\hline
\end{tabular}


Peters, L.D., Pressey, A.D., and Johnston, W.J. (2016). Contagion and learning in business networks, Industrial Marketing Management, forthcoming.

\begin{tabular}{|c|c|c|}
\hline $\begin{array}{l}\text { with others in the network) } \\
\text { vs. } \\
\text { Barriers to contagion } \\
\text { through isolation. }\end{array}$ & $\begin{array}{l}\text { established was the main feature of } \\
\text { ContinuousProject. } \\
\text { Thus, contagion within ties may be } \\
\text { strong but contagion between ties may } \\
\text { be weaker. Worries of isolation were } \\
\text { reflected in the concerns of network } \\
\text { members over the lack of an integrated } \\
\text { and shared I.T. system to share } \\
\text { information across such tie gaps. } \\
\text { However, a wide variety of artefacts } \\
\text { was used by network members to help } \\
\text { overcome isolation, in particularly in } \\
\text { the face of differing professional } \\
\text { backgrounds and training.. }\end{array}$ & $\begin{array}{l}\text { were more cohesive. This closeness of the } \\
\text { existing ties could be a reflection of the } \\
\text { nature of some of these ties (in particular } \\
\text { the trust and friendship between the fit- } \\
\text { out phase project manager and the fit-out } \\
\text { contractor). It was primarily this } \\
\text { relationship that moved the project } \\
\text { forward from concept to commissioning. } \\
\text { In addition, there were more "missing" } \\
\text { links on FragmentedProject which led to } \\
\text { a less dense network structure. The } \\
\text { fragmented two-phase nature of the } \\
\text { project led to less intermediation between } \\
\text { network members and thus greater } \\
\text { isolation. Particularly in phase two, there } \\
\text { was little evidence of the use of artefacts } \\
\text { (i.e. agendas, minutes of meetings, } \\
\text { progress photos) to support the contagion } \\
\text { of ideas. }\end{array}$ \\
\hline $\begin{array}{l}\text { Contagion by structural } \\
\text { equivalence } \\
\text { (i.e. where influence is } \\
\text { related to the structural } \\
\text { patterns of relationships in } \\
\text { the network) } \\
\text { vs. }\end{array}$ & $\begin{array}{l}\text { Although hierarchical in structure, the } \\
\text { nature of progression on the project } \\
\text { and greater connections between } \\
\text { network members meant that } \\
\text { ContinuousProject members were less } \\
\text { immune to contagious messages as } \\
\text { they may have come from several } \\
\text { sources in the network (i.e. not just } \\
\text { 'top-down'). }\end{array}$ & $\begin{array}{l}\text { Hierarchy in the FragmentedProject } \\
\text { network was more pronounced, and while } \\
\text { this may have led to greater efficiency in } \\
\text { network communications (in particular } \\
\text { the transfer of the design team to the } \\
\text { contractor in phase one), it may also have } \\
\text { led to less effectiveness in that it } \\
\text { reinforced the more fragmented nature of } \\
\text { the two-phase project. }\end{array}$ \\
\hline $\begin{array}{l}\text { Barriers to contagion } \\
\text { through immunity. }\end{array}$ & $\begin{array}{l}\text { This openness to 'message infection' } \\
\text { could be seen by the more extensive } \\
\text { use of humour between network } \\
\text { members. }\end{array}$ & $\begin{array}{l}\text { There were fewer connections overall } \\
\text { between network members, so the range } \\
\text { of the network was smaller. In addition, } \\
\text { frequency of communication was less. } \\
\text { Strongly hierarchical formal } \\
\text { communication may have accentuated } \\
\text { immunity to message content in the } \\
\text { network. }\end{array}$ \\
\hline
\end{tabular}

Having presented our data and main findings, we now go on to discuss how contagion

theory may help us understand aspects of network learning.

\section{Contagion and network learning}

The purpose of this study was to examine network learning through the application of contagion theories. So, how did contagion manifest in each of the projects studied, and how did this relate to learning? In both cases, we observed several contagion mechanisms related 
Peters, L.D., Pressey, A.D., and Johnston, W.J. (2016). Contagion and learning in business networks, Industrial Marketing Management, forthcoming.

to exposure to attitudes, information and behaviour. These included face-to-face negotiation, social influence, and the use of simple project artefacts.

\subsection{Face-to-Face negotiation}

Face-to-face negotiation was evident in the numerous informal site meetings. During these ad hoc meetings network members (often through a process of trial and error, and experimentation) would attempt to resolve situations where the design was not feasible or practical. They often took pleasure from these situations, and from drawing on the expertise at hand on the site rather than necessarily through formal lines of reporting. Thus, learningby-interacting enabled similarities in attitudes and coherence in the ongoing design and build of the project, particularly between network members who were not directly connected (or tied) in the network. Influence was also exerted through friendship networks. For example, FragmentedProject was initiated based on the friendships between network members who began informal discussions concerning the adoption of a perceived high-risk technology.

While the routines and practices established through face-to-face negotiation fostered learning-by-doing in both ContinuousProject and the first phase of FragmentedProject, in that regular monthly meetings with established behaviours and routines (such as the review of progress, health and safety, supplier reports, design variations, and design decisions etc.) took place, this was markedly absent on the second phase of FragmentedProject. In fact, on the second (fit-out) phase of FragmentedProject it seems that learning-by-interaction between two main network members attempted to act as a substitute for learning-by-doing. Thus, convergence in attitudes and actions, particularly as the task ambiguity was high in phase two of the project, was diminished on FragmentedProject. 
Peters, L.D., Pressey, A.D., and Johnston, W.J. (2016). Contagion and learning in business networks, Industrial Marketing Management, forthcoming.

Learning by interaction and learning-by-doing were valuable outcomes of face-to-face negotiation. However, there were trade-offs between knowledge spill-overs that can occur when co-location is a feature of the network versus a-spatial relational networks which are formed irrespective of geography. In the end, specialist expertise and/or experience may mitigate the positive effects of face-to-face negotiation as a mechanism for contagion.

\subsection{Social Influence}

Social influence through good-natured humour was used between actors as a socialising mechanism in both projects studied, but it also acted as a valuable means of emphasising expectations and defusing tensions. Thus, humour acted not only as a mechanism to foster learning-by-interacting, but also helped to reduce immunity by lessening the undesirable content of messages, and thus facilitate contagion between actors. An example of this was observed in the first (or build) phase of FragmentedProject when a contractor joked about completing projects for the client who he said would inevitably view these as "..."just-too-late' delivery" in a team meeting. All participants in the meeting (including the client) laughed at this remark; however, it did serve as a gentle admonishment to the client, who they felt harboured unrealistic assumptions concerning the completion of projects that often have high degrees of ambiguity and novelty. Thus humour may be used as a devise for diffusing difficult situations and communicating expectations (Hatch, 1997). However, such humour was not a feature of interactions on the second (fit-out) stage of the project, and this may help explain why communication on the FragmentedProject was more strongly hierarchal in nature.

Another instance of humour was the actions of one team member during a team meeting for ContinuousProject. In the initial meetings between the contractor and the client 
Peters, L.D., Pressey, A.D., and Johnston, W.J. (2016). Contagion and learning in business networks, Industrial Marketing Management, forthcoming.

teams both groups had occupied adjacent positions opposite one another in the room. In one meeting an engineer remarked on this and made a joke about the situation, he then (rather theatrically) got up, walked across the room, and sat with the contractor. Although team members laughed at his observation this also served as a veiled reminder that they would collectively fail or succeed as a group rather than individuals and that the project was ultimately a team endeavour. Thus, humour facilitated learning-by-interacting in that it fostered a feeling of affiliation (Coser, 1959).

\subsection{Artefacts}

A series of simple artefacts acted as a useful mechanism to achieve co-ordination in both projects and to overcome impediments to contagion such as isolation due to specialist or professional knowledge barriers. This included the use of drawings, progress charts, reports, and photographs, all of which served as boundary spanning objects between actors and their cognitive boundaries and provided ways of sharing knowledge on both construction projects. Consequently, the artefacts helped actors to breach each other's cognitive boundaries and to help ensure cognitive consistency across tasks. The lack of such artefacts on the second stage of FragmentedProject could be one reason why learning-by-using may have suffered on this project. A strongly hierarchical structure, particularly for formal communication modes, meant that immunity to message content could have been a more serious issue and prove a barrier to contagion.

In summary, face-to-face negotiation and social influence provided actors with opportunities for learning-by-interacting (learning from joint problem solving with other actors) where knowledge equilibrium is achieved through interaction that facilitates developing similarities in attitudes. They also provided actors with opportunities for learning- 
Peters, L.D., Pressey, A.D., and Johnston, W.J. (2016). Contagion and learning in business networks, Industrial Marketing Management, forthcoming.

by-doing (undertaking what might be routine and repetitive, but often challenging, tasks with other actors), which helps foster convergence in attitudes and actions. The use of simple artefacts provided opportunities for learning-by-using (breaching cognitive boundaries through shared artefacts), which facilitated the effects of social influence, particularly in the face of ambiguity and novelty. We summarise this in Table 5.

Table 5

Contagion and Learning Opportunities

\begin{tabular}{|l|l|l|}
\hline Mechanisms for Contagion & \multicolumn{1}{|c|}{ Purpose } & \multicolumn{1}{|c|}{ Learning Opportunities } \\
\hline $\begin{array}{l}\text { Face-to-face negotiation } \\
\text { (informal meetings, in situ, } \\
\text { ad hoc, interlocking, } \\
\text { friendship networks) }\end{array}$ & $\begin{array}{l}\text { Ensure consistency, Negotiate } \\
\text { consensus }\end{array}$ & $\begin{array}{l}\text { Opportunities for learning-by- } \\
\text { interacting and for learning-by- } \\
\text { doing }\end{array}$ \\
\hline $\begin{array}{l}\text { Social influence } \\
\text { (humour, gentle } \\
\text { admonishing, socializing) }\end{array}$ & $\begin{array}{l}\text { Expressing expectations, Managing } \\
\text { expectations }\end{array}$ & $\begin{array}{l}\text { Opportunities for learning-by- } \\
\text { interacting }\end{array}$ \\
\hline $\begin{array}{l}\text { Artefacts } \\
\text { (drawings, progress charts, } \\
\text { reports, photographs) }\end{array}$ & $\begin{array}{l}\text { Maintaining consistency, } \\
\text { interpretation, and practices }\end{array}$ & Opportunities for learning-by-using \\
\hline
\end{tabular}

\section{Conclusions}

Drawing on the disease metaphor underpinning contagion theories, we examined network members' exposure to the knowledge, attitudes and behaviours of other actors. We found that through the practices and processes of contagion (e.g. cohesion and structural equivalence), important learning opportunities (i.e. by doing, using, and interacting) for enhancing social integration and cognitive consistency were offered. By the same token, we found that resistance to contagion might come from a lack of exposure (i.e. isolation) and/or a resistance to change based on pre-existing attitudes and beliefs formed through exposure to a weaker form of a contagious network message (i.e. immunity). 
Peters, L.D., Pressey, A.D., and Johnston, W.J. (2016). Contagion and learning in business networks, Industrial Marketing Management, forthcoming.

This study responds to calls for research into knowledge and learning at the level of an interfirm network (Lambooy, 2004; Maggioni et al. 2007). More specifically, it focuses on developing an understanding of how the contagion of knowledge and ideas and the coordination of activities within a network tales place. We achieve this by drawing upon research in both network relationships dynamics (Walls and Paquin, 2015) and learning processes in newer organisational forms, such as flat networks (Oswick and Grant, 2015), to investigate the causal mechanisms that drive contagion. We therefore address the gap identified by Iyengar et al. (2011) by examining not just whether, but also how, the transmission of knowledge, sharing of resources, and facilitation of innovation takes place through contagion. By focusing on the social practices of the network members, we embed knowledge development and dissemination within the legitimised social practices observed, as extolled by Jones (2014). Specifically, we develop a more complex understanding of how actors are exposed to attitudes, behaviour, and information and how this diffuses through networks. Further, in response to the critics of contagion theories we have not assumed that exposure to information "injects" values and attitudes in others (Monge and Contractor, 2003), but have considered the mechanisms that trigger contagion, and the practices by which organisations influence other's actions and behaviour.

Instances of behaviour and attitude change through contagion were evidenced, and offered insights into managerial practice in such networks. In particular, face-to-face negotiation (influenced by personal relationships such as friendship ties) offers opportunities to ensure consistency and consensus. Socialisation mechanisms such as the use of humour in more formal communication settings and the instigation of a team expedition to a similar project to benchmark progress and help problem-solve common issues, provided important contagion opportunities to learn. Finally, the use of artefacts (e.g. drawings, progress charts, 
Peters, L.D., Pressey, A.D., and Johnston, W.J. (2016). Contagion and learning in business networks, Industrial Marketing Management, forthcoming.

reports, and photographs in particular) may offer important opportunities to bring together fragmented expertise and enhance the clustering of project communication behaviour in strongly hierarchical project structures.

Project structure also provided an insight into possible barriers to contagion. In particular, on FragmentedProject the two-stage nature of the project (the building structure followed by the equipment fit-out) led to difficulties of co-ordination, isolation, and immunity to learning by members of the network. Therefore, project structure needs to be considered as an important feature of network learning. Considerations of network structure to enhance the effectiveness or efficiency of network operations needs to be balanced with the impact on communication behaviours and contagion in the network.

By examining contagion in the construction industry, this research offers practitioners implications regarding network learning through actors' exposure to information, attitudes and behaviour, as well as the configuration and management of networks to ensure actors are not 'immune' to network learning opportunities. Particularly relevant here are levels of network cohesion, which emphasises the importance of ensuring network connections between actors. One method of achieving this is the use and dissemination of simple project artefacts (including drawings, progress charts, reports, and photographs), all of which served as boundary spanning objects between actors (particularly with actors from different specialised fields), and their cognitive boundaries, and provided ways of sharing knowledge on both construction projects.

A second area of practical importance relates to structural equivalence, where the patterns and nature of relationships are significant in order that networks are open to 
Peters, L.D., Pressey, A.D., and Johnston, W.J. (2016). Contagion and learning in business networks, Industrial Marketing Management, forthcoming.

'message infection' This can be facilitated in part through face-to-face negotiation, the importance of utilising friendship networks, as well as the level of social influence at play within a network (for example, the role of humour in networks, clearly something that is difficult to manage, but is something that should not be discouraged). In sum, network contagion opportunities (providing optimum network learning opportunities), will be related to the extent to which networks are configured to provide sufficient opportunities for learning-by-interacting, learning-by-doing, and learning-by-using.

As a contributor to theory building, our findings do recognise key aspects of contagion in organisational networks. Further evidence from alternative cases in other industries or contexts would further extend this work in relation to the how and why of contagion in networks, as would alternative methodologies which could seek to statistically generalise the what, where, how, and who, of contagion in networks. Additional research could enrich the literatures on network learning, industrial marketing, and economic geography by focusing on issues such as the specific conditions under which these causal mechanisms operate, and how they may differ in alternative settings or industries. For example, to what extent might specialist expertise or experience mitigate the lack of face-toface contact as a mechanism for contagion in non-co-located networks? Are there contexts in which the use of humour might act as a barrier rather than a facilitator of learning? Are there interaction effects between face-to-face negotiation and the use of artefacts in learning processes? How can artefacts be used in non-co-located networks?

\section{References}

Amin, A., and Thrift, N., (2000). What kind of economic theory for what kind of economic geography? Antipode, 32(1): 4-9. 
Peters, L.D., Pressey, A.D., and Johnston, W.J. (2016). Contagion and learning in business networks, Industrial Marketing Management, forthcoming.

Amin, A., (2001). Moving on: Institutionalism in economic geography, Environment and Planning A, 33: 1237-1241.

Araujo, L. (1998). Knowing and learning as networking. Management Learning, 29 (3), 317336.

Bångens, L., \& Araujo, L. (2002). The structures and processes of learning: a case study. Journal of Business Research, 55 (7), 571- 581.

Bartsch, V., Ebers, M. and Maurer, I., (2013). Learning in project-based organizations: The role of project teams' social capital for overcoming barriers to learning. International Journal of Project Management, 31(2), 239-251.

Bathelt, H., and Spigel, B., (2012). The spatial economy of North American trade fairs, The Canadian Geographer, 56(1): 18-38.

Bathelt, H., and Glückler, J., (2011). The relational economy: Geographies of knowing and learning, Oxford University Press: Oxford.

Bathelt, H., and Glückler, J., (2003). Toward a relational economic geography, Journal of Economic Geography, 3(2): 117-144.

Boggs, J.S. and Rantisi, N.M., (2003). The 'relational turn' in economic geography, Journal of Economic Geography, 3(2): 109-116.

Brown, J. S., \& Duguid, P. (1991). Organizational Learning and communities-of-practice. Organization Science, 12, 198-213.

Brusoni, S. (2005). The limits to specialization: Problem solving and coordination in 'modular networks'. Organization Studies, 26, 1885-1907.

Burt, R. S. (1980). Models of network structure. Annual Review of Sociology, 6, 79-141.

Burt, R. S. (1987). Social contagion and innovation: Cohesion versus structural equivalence, American Journal of Sociology, 92 (6): 1287-1335. 
Peters, L.D., Pressey, A.D., and Johnston, W.J. (2016). Contagion and learning in business networks, Industrial Marketing Management, forthcoming.

Burt, R. S. (2004). Structural holes and good ideas. American Journal of Sociology, 110: 349399.

Cabrera, A. \& Cabrera, E. (2002). Knowledge-sharing dilemmas. Organization Studies, 23(5), 687-710.

Cacciatori, E. (2008). Memory objects in project environments: Storing, retrieving and adapting learning in project-based firms. Research Policy, 37(9), 1591-1601.

Carley, K. (1991). A theory of group stability. American Sociological Review, 56, 331-354.

Carlile, P. R. (2004). Transferring, translating, and transforming: An integrative framework for managing knowledge across boundaries. Organization Science, 15(5), 555-568.

Chiu, Y. T. (2009). How network competence and network location influence innovation performance. Journal of Business \& Industrial Marketing, 24 (1), 46 - 55.

Certomà, C., (2011). Standing-up vineyards: the political relevance of Tuscan wine production, Environment and Planning D: Society and Space, 29(6): 1010 - 1029.

Cornelissen, J. (2005). Beyond compare: metaphor in organisation theory, Academy of Management Review, 30 (4), pp 751-764.

Corsaro, D., Cantù, C. \& Tunisini, A. (2012). Actors' Heterogeneity in Innovation Networks, Industrial Marketing Management, 41: 780-798.

Coser, R. L. (1959). Some social functions of laughter: A study of humour in a hospital setting. Human Relations, 12, 171-182.

Crang, P., (1997). Introduction: cultural turns and the (re)constitution of economic geography, In Lee, R. and Wills, J., editors, Geographies of Economies, London: Arnold, 3-15.

Dubois, A., \& Gadde, L. (2002). The construction industry as a loosely coupled system: implications for productivity and innovation. Construction Management and Economics, 20, 621-631. 
Peters, L.D., Pressey, A.D., and Johnston, W.J. (2016). Contagion and learning in business networks, Industrial Marketing Management, forthcoming.

Easterby-Smith, M., Crossan, M., \& Nicolini, D. (2000). Organisational learning: debates past, present and future. Journal of Management Studies, 37 (6), 783-796.

Esser, J. K. (1998). Alive and well after 25 years: A review of groupthink research, Organisational Behaviour and Human Decision Processes, 73(2/3): 116-141.

Ettlinger, N., (2003). Cultural economic geography and a relational and microspace approach to trusts, rationalities, networks, and change in collaborative workplaces, Journal of Economic Geography, 3(2): 145-171.

Faulconbridge, J. R., (2007). Relational networks of knowledge production in transnational law firms, Geoforum, 38(5): 925-940.

Festinger, L. (1957). A Theory of Cognitive Dissonance. Stanford CA: Stanford Uni. Press.

Feeley, T. H., \& Barnett, G. A. (1996). Predicting employee turnover from communication networks. Human Communication Research, 23, 370-387.

Fitjar, R., and Rodríguez-Pose, A. (2015). Networking, context and firm-level innovation: Cooperation through the regional filter in Norway, Geoforum 63: 25-35.

Friedkin, N. E. (1984). Structural cohesion and equivalence explanations of social homogeneity. Sociological Methods and Research, 12, 235-261.

Frigant, V. \& Lung, Y. (2002). Geographical proximity and supplying relationships in modular production, International Journals of Urban and Regional Research, 26 (4): $742-755$.

Geldes, C., Felzensztein, C. Turkina, E. and Durand, A. (2015). How does proximity affect interfirm marketing cooperation? A study of an agribusiness cluster. Journal of Business Research 68: 263-272.

Giuliani, E., (2007). The selective nature of knowledge networks in clusters: evidence from the wine industry, Journal of Economic Geography, 7(2): 139-168. 
Peters, L.D., Pressey, A.D., and Johnston, W.J. (2016). Contagion and learning in business networks, Industrial Marketing Management, forthcoming.

Grabher, G. (2006). Trading routs, bypasses, and risky intersections: mapping the travels of 'networks' between economic sociology and economic geography, Progress in Human Geography, 30 (2): 163-189.

Grabher, G. and Ibert, O. (2006). Bad company? The ambiguity of personal knowledge networks. Journal of Economic Geography 6: 251-271.

Granovetter, M. (1978). Threshold models of diffusion and collective behaviour. Journal of Mathematical Sociology, 9, 165-179.

Granovetter, M. (1985). Economic Action and Social Structure: The Problem of Embeddedness, American Journal of Sociology, 91 (3): 481-510.

Håkansson, H., \& Ford, D. (2002). How should companies interact in business networks? Journal of Business Research, 55, 133-139.

Hanneman, R. A., \& Riddle, M. (2005). Introduction to social network methods. University of California: Riverside, CA. retrieved from http://faculty.ucr.edu/ hanneman/

Hatch, M. J. (1997). Irony and the social construction of contradiction in the humour of a management team. Organization Science, 8, 275-288.

Hurley, R. \& Hult, T. (1998). Innovation, Market Orientation, and Organizational Learning: An Integration and Empirical Examination. The Journal of Marketing, 62 (3), 42-54

Iyengar, R., Van den Bulte, C. \& Choi, J. (2011). Distinguishing among mechanisms of social contagion in new product adoption: framework and illustration, MSI Report no. 11-119, Cambridge, MA.: Marketing Science.

Johnston, W. J., Peters, L. D. \& Gassenheimer, J. B. (2006). Questions about Network Dynamics: Characteristics, Structures, and Interactions, Journal of Business Research, $59,945-954$.

Jones, A., (2014). Geographies of production I: Relationality revisited and the 'practice shift' in economic geography, Progress in Human Geography, 38(4): 605-615. 
Peters, L.D., Pressey, A.D., and Johnston, W.J. (2016). Contagion and learning in business networks, Industrial Marketing Management, forthcoming.

Jones, A., and Murphy, J., (2011). Theorizing practice in economic geography: foundations, challenges, and possibilities, Progress in Human Geography, 35(3): 366-392.

Kauppila, O., Rajala, R., \& Jyrämä, A. (2011). Knowledge sharing through virtual teams across borders and boundaries. Management Learning, 42, 371-377.

Kilduff, M. (1992). The friendship network as a decision-making resource: disposition moderators of social influences on organizational choice. Journal of Personality and Social Psychology, 62, 168-180.

Knight, L \& Pye, A (2005). Network learning: an empirically-derived conceptual model of learning by groups of organizations, Human Relations, 58 (3): 369-392.

Krackhardt, D., \& Brass, D. J. (1994). Intra-organizational networks: the micro side. In S. Wasserman \& J. Galaskiewicz (Eds.), Advances in social network analysis: research in the social and behavioural sciences (pp. 207-229). Thousand Oaks, CA: Sage.

Krackhardt, D., \& Porter, L. (1986). The snowball effect: turnover embedded in social networks. Journal of Applied Psychology, 71, 50-55.

Krassa, M. A. (1988). Social groups, selective perception, and behavioural contagion in public opinion. Social Networks, 10, 109-136.

Lambooy, J. (2004). The transmission of knowledge, emerging networks, and the role of universities: An evolutionary approach, European Planning Studies, 12 (5): 643-657.

Lettl, C., Herstatt, C., \& Gemuenden, H. (2006). Users' contributions to radical innovation: evidence from four cases in the field of medical equipment technology. $R \& D$ Management, 36(3), 251-272.

Loasby, B. J. (1998). The organisation of capabilities. Journal of Economic Behaviour and Organization, 35, 139-160.

Mason, K., \& Easton, G. (2009). Boundary Objects and Buyer - Seller Relationships, 25th IMP-conference, Marseille, France. 
Peters, L.D., Pressey, A.D., and Johnston, W.J. (2016). Contagion and learning in business networks, Industrial Marketing Management, forthcoming.

McGuire, W. J. (1966). Attitudes and opinions. Annual Review of Psychology, 17, 475-514.

Maggioni, M., Nosvelli, M. \& Uberti, T. (2007). Space versus networks in the geography of innovation: A European analysis, Papers in Regional Science, 86 (3): 471-493.

Mohr, J. and Nevin, J. (1990). Communication Strategies in Marketing Channels: A Theoretical Perspective, Journal of Marketing, October, pp. 36-51.

Monge, P. R., \& Contractor, N. S. (2003). Theories of communication networks, New York: Oxford University Press.

Morgan, G. (1986). Images of Organisation, Thousand Oaks, CA: Sage.

Morgan, G. (2011). Reflections on images of organisation and its implication for organisation and environment, Organisation \& Environment, 24 (4), 459-478.

Muller, M. (2015). A half-hearted romance? A diagnosis and agenda for the relationship between economic geography and actor-network theory, Progress in Human Geography, 39 (1): 65-86.

Murphy, J., (2006). The sociospatial dynamics of creativity and production in Tanzanian industry: Urban furniture manufacturers in a liberalizing economy, Environment and Planning A, 38(10): 1863-82.

Oswick, C. \& Grant, D. (2015). Re-imagining images of organisation: A conversation with Gareth Morgan, Journal of Management Inquiry (pp. 1-6), accessed online first November 3, 2015.

Pain, K., (2008). Spaces of practice in advanced business services: rethinking LondonFrankfurt relations, Environment and Planning D: Society and Space, 26(2): 264-279.

Pattison, P. (1994). Social cognition in context: some applications of social network analysis. In S. Wasserman \& J. Galaskiewicz (Eds.), Advances in social network analysis: research in the social and behavioural sciences (pp. 79-109). Thousand Oaks, CA: Sage. 
Peters, L.D., Pressey, A.D., and Johnston, W.J. (2016). Contagion and learning in business networks, Industrial Marketing Management, forthcoming.

Popova-Nowak, I. \& Cseh, M. (2015). The meaning of organisational learning: A metaparadigm perspective, Human Resource Development Review, 14 (3): 299-331.

Rentsch, J. R. (1990). Climate and culture: interaction and qualitative differences in organizational meetings. Journal of Applied Psychology, 75, 668-681.

Rice, R. E. (1993). Using network concepts to clarify sources and mechanisms of social influence. In G. Barnett \& W. Richards, Jr. (Eds.), Advances in communication network analysis, 1-21. Norwood, NJ: Ablex.

Robey, D., Khoo, H. M., \& Powers, C. (2000). Situated Learning in Cross-functional Virtual Teams. IEEE Transactions on Professional Communication, 43(1), 51-66.

Rogers, E. M., \& Kincaid, D. L. (1981). Communication networks: towards a new paradigm for research. New York: Free Press.

Roy, D. (1959). Banana time: Job satisfaction and informal interaction, Human Organization, $18,158-168$.

Rutten, R., (2016). Beyond proximities: The socio-spatial dynamics of knowledge creation, Progress in Human Geography.

Sole, D. \& Edmondson, A. (2002). Situated knowledge and learning in dispersed teams, British Journal of Management, 13 (2), 17-34.

Strauss, A., \& Corbin, J. (1998). Basics of Qualitative Research (2 ${ }^{\text {nd }}$ Ed.). London, UK: Sage. Walker, G. (1985). Network position and cognition in a computer software firm. Administrative Science Quarterly, 30, 103-130.

Walls, J. \& Paquin, R. (2015). Organisational perspectives of industrial symbiosis: A review and synthesis, Organisation \& Environment, 28 (1): 32-53.

Walsh, J. P. (1988). Selectivity and Selective Perception: An Investigation of Managers' Belief Structures and Information Processing, The Academy of Management Journal 31 (4), 873-896. 
Peters, L.D., Pressey, A.D., and Johnston, W.J. (2016). Contagion and learning in business networks, Industrial Marketing Management, forthcoming.

Watson, A., (2012). Sociological Perspectives on the Economic Geography of Projects: The Case of Project-Based Working in the Creative Industries, Geography Compass, 6(10): 617-631.

Weick K. E., \& Roberts, K. H. (1993). Collective mind in organizations: Heedful interrelating on flight decks, Administrative Science Quarterly, 38, 357-381.

White, D. R., \& Reitz, K. P. (1989). Rethinking the role concept: homomorphisms on social networks. In L. C. Freeman, D. R. White \& A. K. Romney (Eds.), Research methods in social network analysis (pp. 429-488), Fairfax, VA: George Mason University Press.

Yeung, H. W. C., (2005). Rethinking relational economic geography, Transactions of the Institute of British Geographers, 30(1): 37-51.

Yin R. K. (1994). Case study research: design and methods. London, UK: Sage. 
Peters, L.D., Pressey, A.D., and Johnston, W.J. (2016). Contagion and learning in business networks, Industrial Marketing Management, forthcoming.

\section{Appendix 1}

\section{Sociograms for ContinuousProject}

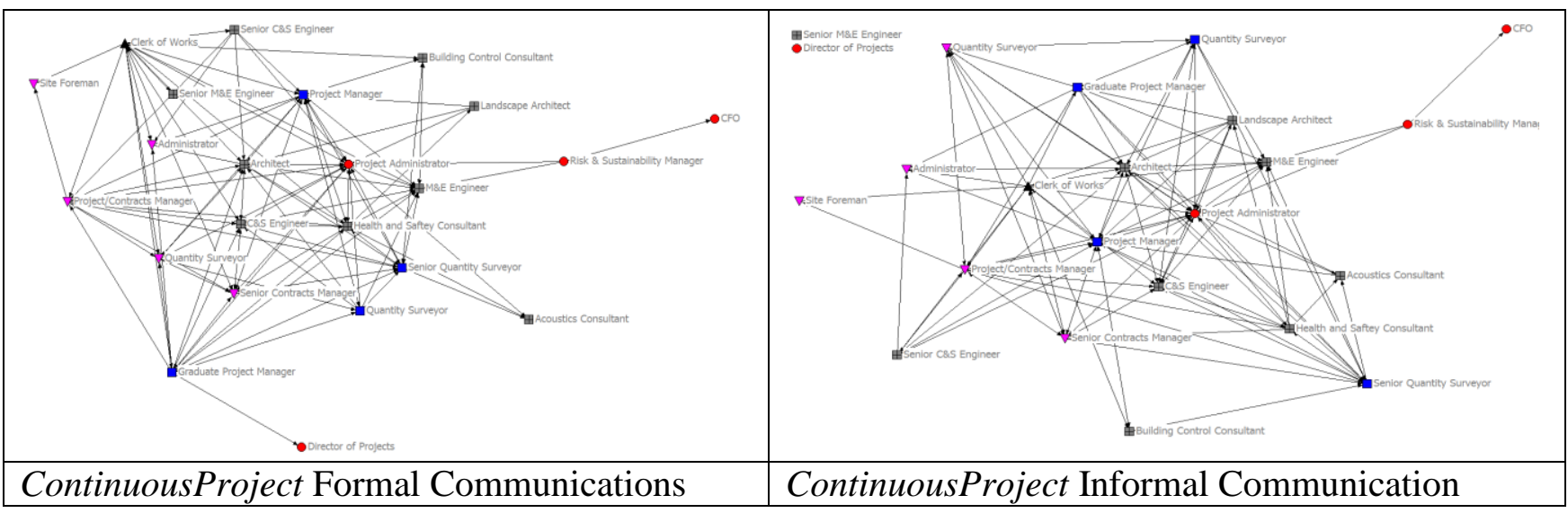

Sociograms for FragmentedProject

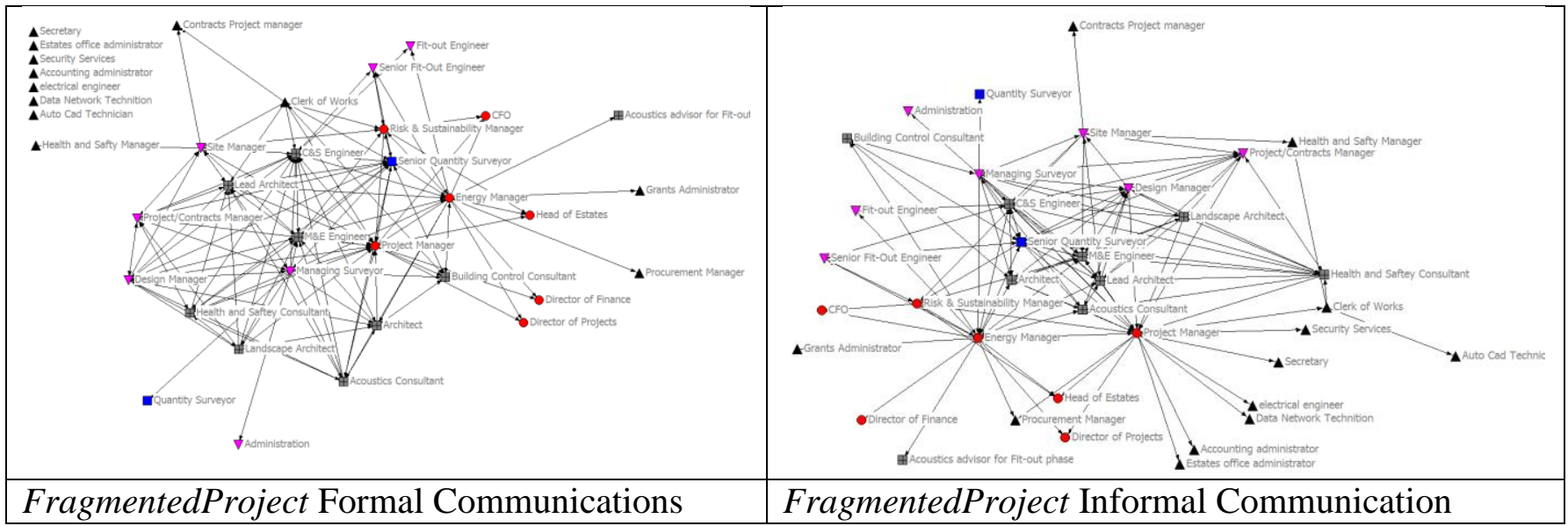

